\title{
$\mathrm{RBAC}$ 에 기반한 개인 맞춤형 건강 정보 제공 헬스케어 서비스 플랫폼 송제민 ${ }^{1}$, 김명식 ${ }^{2}$, 정경지 ${ }^{3}$, 신문선 ${ }^{*}$ ${ }^{1}$ 터보소프트(주), ${ }^{2}$ 네오포스(주) \\ ${ }^{3}$ 충청대학교 국방정보통신과, ${ }^{4}$ 건국대학교 과학기술대학 컴퓨터공학과
}

\section{RBAC-based health care service platform for individual recommended health information service}

\author{
Je-Min Song ${ }^{1}$, Myung-Sic Kim ${ }^{2}$, Kyeong-Ja Jeong ${ }^{3}$ and Moon-Sun Shin ${ }^{4^{*}}$ \\ ${ }^{1}$ TurboSoft, ${ }^{2}$ Neoforce \\ ${ }^{3}$ Dept. of Military Information \& Communications, Chung Cheong University \\ ${ }^{4}$ Dept. of Computer Engineering, Konkuk University
}

\begin{abstract}
요 약 개인 맞춤형 헬스 케어 서비스 플랫폼은 개인별 건강관리를 위하여 다양한 건강정보 데이터를 저장 관리하 고 건강정보 제공 및 건강 가이드 서비스를 제공하기 위한 헬스 케어 서비스 플랫폼으로 개인의 프라이버시와 개인 정보보호를 전제조건으로 서비스 되어야 한다. 본 논문에서는 개인의 역할에 따른 보안서비스를 기반으로 제공되는 개인 맞춤형 헬스케어 서비스 플랫폼을 제안한다. 제안된 개인 맞춤형 헬스 케어 서비스 플랫폼은 병원에서 측정하는 기초 임상, 영상, 약물 데이터에 대한 저장 및 관리뿐만 아니라 개인적으로 획득할 수 있는 건강 정보, 즉 스마트 기 기에서 측정 및 입력 가능한 음식물, 수면, 감정, 운동에 대한 데이터를 종합적으로 관리하여 일상생활에서 개인별 건 강정보를 관리할 수 있도록 하여 현대인들의 스마트한 건강생활을 지원하는 기능을 제공하는 서비스 플랫폼에 역할 기반 접근제어 모델을 적용하여 개인의 사생활 및 개인 정보 침해를 방지할 수 있도록 하였다. 제안된 RBAC 기반의 스마트 헬스 케어 서비스 플랫폼은 구현환경에 따라서 다양한 사용자와 사용자의 역할 및 권한 등을 설정하여 유연 하게 개인 정보보호를 할 수 있는 시스템으로 구축되어 개인 맞춤형 건강정보 서비스를 제공할 수 있다.
\end{abstract}

\begin{abstract}
In this paper, we propose an RBAC based personalized health care service platform in order to provide smart management of personal health record using smart devices. It helps to guide healthful service and provide useful information according to one's individual health record.

Personalized health care services platform supports a healthy lifestyle by measuring personal health information in a hospital clinical, imaging, and drug data, as well as that can be obtained from smart devices. Everyone can enter his health related data in everyday life such as food, sleeping time, mood, movement and exercise so that one can manage his personal health information of modern smart features.

In addition, if necessary, personal health information can be provided to the hospital information system and staff with the consent of the individual. It can be contributed to simplify the complex process for remote medical.

The proposed platform, which applies role based access control model to protect security and privacy, supports a smart health care services for users by providing personalized health care services through the smart applications.
\end{abstract}

Key Words : healthcare service platform, personalized healthcare, personal health record, RBAC(Role Based Access Control)

*Corresponding Author : Moon-Sun Shin(Konkuk University)

Tel: 82-43-840-3602 email: msshin@kku.ac.kr

Received October 22, 2013 Revised December 17, 2013 Accepted March 6, 2014 


\section{1. 서론}

최근의 유비쿼터스 환경은 개인 맞춤형 서비스 지원과 특정 영역을 지원하는 소프트웨어 서비스 플랫폼 기술로 더욱 유용해졌으며 특히 헬스케어는 원격의료 기술을 활 용하여 시간과 공간의 제한 없이 의료 서비스를 제공받 을 수 있어 건강 100 세 시대, 고령화 사회의 진입시점에서 더욱 큰 관심을 받고 있다. 특히 의료기술과 IT융합기술 의 발달로 건강한 생활을 위한 관심과 소비가 증가하고 있다. 또한 IT 기술의 발달과 융·복합 기술의 진화로 스마 트 기기와 휴대용 생체정보 수집 디바이스를 통해 언제 어디서나 손쉽게 자신의 건강 상태 정보를 수집하고 관 리할 수 있게 되었다. 최근 다양한 스마트 기기의 보급이 가속화되면서 모바일 헬스케어 애플리케이션 시장의 규 모도 점점 커지고 있다. 글로벌데이터의 조사에 따르면 2018년까지 모바일 헬스케어 시장은 80억 달러 규모로 성장할 것으로 전망되고 있다. 통신기술 발달과 함께 주 목받고 있는 헬스케어는 만성질환을 않는 고령인구가 많 고 원격의료 기술이 발달한 선진국이 연구 개발을 주도 하여 왔다[5-8].

의료진들은 좀 더 효율적으로 환자를 진료하고 환자에 게 치료과정을 보여주거나 회복 상태를 보여주는 등 환 자와의 소통을 위해서 헬스케어 앱을 사용하고 있으며 환자들은 의학 교육용 정보를 전송받거나 자신의 상태에 대한 질문 등을 의사에게 하고 답변도 손쉽게 전송받을 수 있는 앱들이 활용되고 있다.

지금까지 $\mathrm{u}$-헬스케어 서비스는 병원 중심으로 병원정 보시스템의 데이터베이스에 저장되어 관리되었으며, 환 자들은 진료 기록 및 영상 데이터를 병원으로부터 매번 일정한 수수료를 지불하고 $\mathrm{CD}$ 에 담아 타 병원에 제출하 는 방식이었으며 이를 지속적으로 보관 관리 하는 데 어 려움이 많았다[3].

환자 중심의 의료 서비스 플랫폼을 활용하게 되면 의 료 서비스가 제공되는 공간이 의료기관 내에서 가정, 휘 트니스클럽, 업무영역 등 일상생활 영역으로 확대 (예: 휴 대폰을 이용한 당뇨, 심전도, 혈압 관리)되어 병원에 방문 하는 횟수와 반복적으로 검사하는 비용이 절약될 수 있 으며 불필요한 병원 내원으로 국민건강보험 지출 예방과 지속적이고 예방적인 질환 관리가 요구되며, 개인이 손쉽 게 휴대기기를 통해 자신의 헬스 데이터를 관리하며 의 료 서비스 플랫폼을 통해 맞춤형 건강관리 서비스가 가 능하지만 개인의 프라이버시와 정보 침해 등의 문제가 심각해질 수 있다. 따라서 본 논문에서는 역할기반 접근 제어모델을 적용한 개인화 헬스 케어 서비스 플랫폼을 제안한다. 스마트기기를 이용해서 개인의 건강정보를 관
리하고, 건강정보와 관련된 본인의 완치경험이나 타인의 치유과정 정보 등 다양한 형태의 건강 관련 정보를 제공 받을 수 있으며 병원 정보시스템에 저장된 진료기록 및 영상 데이터 보관 및 관리 등을 제공하는 환자중심의 개 인 맞춤형 헬스케어 서비스 플랫폼에 역할 기반 접근제 어 모델을 적용하여 개인의 프라이버시와 정보침해를 방 지할 수 있는 플랫폼을 설계하였다. 본 논문의 구성은 다 음과 같다. 2장에서 국내외 헬스케어 서비스 시장 현황과 맞춤형 헬스케어 서비스 플랫폼 구축의 필요성 및 역할 기반 접근제어모델에 대하여 기술한다. 3장에서는 RBAC 기반의 개인 맞춤형 헬스케어 서비스 플랫폼의 상세 가 능을 정의하고 4장에서는 개인 맞춤형 헬스케어 서비스 플랫폼의 기본 구조를 설계한다. 5 장에서는 결론과 향후 연구에 대해 설명한다.

\section{2. 관련 연구}

\section{1 국내외 헬스 케어 서비스 시장 현황}

홈 헬스케어 혹은 유-헬스케어로 표현되는 헬스케어서 비스는 집에서 네트워크와 연결된 측정기기를 통해 생체 계측을 수행하면, 측정결과가 전문 의료진에게 실시간으 로 전달하고, 전문 의료진이 지속적으로 건강 상태를 모 니터링 함으로써 가정 내에서 1 차적인 건강관리가 가능 한 차세대 의료서비스를 의미한다. 구글 헬스, 마이크로 소프트의 의료 서비스 플랫폼(CHF), PatientLikeMe 등과 같이 기업에서 환자의 질환을 웹 기반에서 손쉽게 관리 하고 유사한 질환을 가진 환자와 소셜 네트워크(SNS)를 구축하여 정보를 교환하는 다양한 서비스가 최근 증가하 고 있다. 기존에 병원에서 환자에게 제공하는 각종 의무 기록(소견서, 처방전, 진단서, 약물처방)이나 영상 데이터 (CT, MRI, X-ray 등)를 $\mathrm{CD}$ 로 받아 환자들이 관리함으로 써 많은 불편함이 발생되고 있다.

현재 $\mathrm{u}$-헬스 서비스 시장은 초기 단계에서 성장단계로 진행 중이며, 의료인 중심의 의료법 때문에 병원중심의 의료 서비스 형태가 주를 이루고 있지만 향후 의료법 및 의료 개방이 이루어 지면 환자 중심의 의료 서비스를 위 해 홈/원격 진료 서비스가 활성화 될 것으로 예상된다. 서 울대 병원에서는 2002년부터 재택 진료 서비스 사업을 시작하였으며, 50 개 시범 가구를 선정하여 영상 시스템, 원격 청진기 등을 갖추어 실제 진료와 동일한 서비스 제 공하고 있다, 또한 포스코 건설은 아이엠넷피아와 제휴하 여 2008년 인천 송도의 주상복합 아파트에 u-health 서비 스를 제공할 계획을 세웠으며, KT, Bionet 등과 협력하여 
모바일 온라인 헬스서비스를 제공하고 있다[5].

국내의 경우 30 세 이상 성인의 $1 / 3$ 이 심뇌혈관질환 고 위험군에 해당되며, 통계청 자료에 의하면 인구 10 만명 당 107 명, 한해 5만 2000여명이 심뇌혈관질환 사망자수 이며, 성인 4 명중 1 명이 고혈압관련 질환으로 추정되고 있으며 성인병과 만성질환은 인간의 삶의 질을 크게 저 하시키기 때문에 사전에 건강한 생활 습관과 자신의 건 강 상태에 대해 기록하고 사전에 검사를 통해 예방하는 것이 필요하다.

현재 우리사회는 고령화 사회로 진입하고 있는 시점에 서 노인과 만성 질환자 의료 수요가 늘어나고 있으며 일 반인들의 건강에 대한 관심이 고조되고 있어서 미래의 건강중심사회의 도래에 따른 준비가 국가적인 차원에서 요구되고 있다. 21 세기를 선도할 주요 성장 동력으로써 서비스 산업이 전망되고 있으며 의료산업화정책이 추진 중에 있다. 특히 현대인들은 식생활 습관변화, 스트레스 등으로 인한 만성 질환의 증가 및 건강에 대한 관심 증가 로 예방. 사후관리 중심의 의료서비스에 대한 수요가 급 증하고 있으며 특히 의료서비스의 패러다임이 전문 의료 기관에서의 급성 질환 서비스 중심에서 일반 가정 보건 의료 서비스 중심으로 변화하고 있다. 일상생활에서 발 생하는 여러 가지 건강정보(음식의 양, 운동의 종류, 운동 량, 등)를 스마트기기에 입력하고 스마트 기기를 통해서 하루에 필요한 식단과 운동에 대한 가이드 및 정신건강 을 위한 여러 가지 맞춤형 정보를 제공받음으로써 개인 이 관리하는데 어려움이 있는 건강생활 정보를 총괄적으 로 관리할 수 있다면 개인의 건강 생활 영위에 큰 도움이 될 것이다. 본 논문에서는 기존의 병원 중심의 의료 데 이터 관리에서 환자 중심의 의료 데이터 관리 서비스 플 랫폼을 제안한다. 제안하는 환자중심 의료데이터 관리 서 비스 플랫폼은 병원에서 측정되는 기초 임상, 영상, 약물 처방 데이터와 스마트 기기에서 측정 또는 사용자가 입 력 가능한 음식물, 수면, 감정, 운동에 대한 데이터를 종 합적으로 관리하고 환자 동의하에 병원정보 시스템 및 특정 의료진에 자신의 건강 정보를 제공하거나 타인에게 제공할 수 있는 의료 서비스 플랫폼의 구축 요구에 부응 하는 헬스케어 3.0시대를 위한 맞춤형 헬스케어 서비스 플랫폼이며 Fig. 1은 환자 중심의 의료서비스 플랫폼의 필요성을 도식화한 것이다.

글로벌 헬스케어 시장은 2010년 기준 약 5조 8000억 달러 규모로 의료서비스 부분이 약 3 조 7000 억 달러, 제 약 1 조 1000 억 달러, 웰빙 7000 억 달러, 바이오 1000 억 달러에 이른다. 앞으로도 지속 고령화 인구 및 만성질환 자의 증가로 년 평균 $4.4 \%$ 성장해 2020년에는 약 9조 달 러 시장에 이를 전망이다.

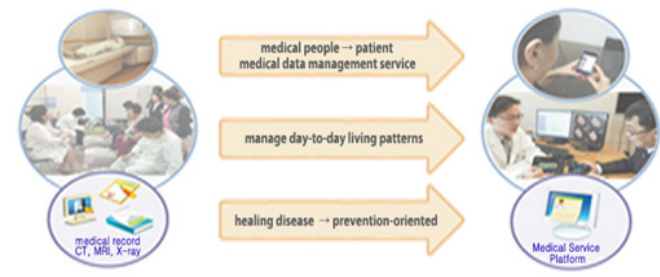

Patient-centered integrated health data management service

[Fig. 1] Patient oriented health care service

국내 헬스케어 시장의 경우 2010년 기준 약 81 조원으 로 GDP대비 6.9\%에 그치고 있지만 2020년에는 256조원 규모로 성장해 GDP 대비 약 $11 \%$ 이상을 차지할 것으로 예상된다. 이에 대기업들은 헬스케어 사업을 미래 먹거리 로 선정하고 다방면의 사업 진출을 모색 중이다. 통신사 들은 자신들이 보유한 ICT기술을 의료에 융합한 스마트 헬스케어 분야로의 진출을 서두르고 있다. SK텔레콤과 서울대학교병원이 설립한 조인트벤처 헬스커넥트는 첫 번째 건강관리 서비스인 '헬스온' 시범서비스를 시작하며 본격적인 헬스케어 시장 진출을 시작했다. 헬스온은 건강 검진과 개인별 평소 건강관리를 연계해 휴대폰 애플리케 이션을 통해 의료진, 영양사, 운동처방사가 지속적인 개 별 상담과 진행 경과를 온 - 오프라인으로 제공하는 서비 스다. 헬스커넥트는 하반기부터 본격적으로 서비스를 시 작할 계획이며 향후 국내 대기업 중심의 확대 및 글로벌 진출을 검토할 예정이다[2].

Fig. 2는 글로벌 기업들의 다양한 u-헬스케어 서비스 모델을 보여주고 있다[6,-9].
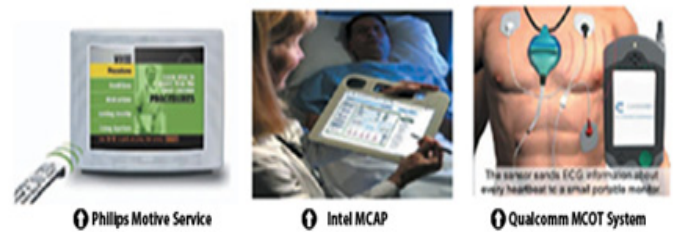

[Fig. 2] U-healthcare Service Model of Global IT Companies

현재 공공 의료복지 분야의 u-Health 서비스는 독거노 인, 생활보호대상자 등 의료 소외계층에 대한 의료서비스 를 우선 적용·확대함으로써 정부(지자체)의 의료 복지서 비스의 질적 개선과 비용절감을 목표로 하고 있다. 그러 나 일반인들을 위한 정부차원의 헬스케어 서비스 지원은 시기적으로 즉각적으로 이루어지기에는 현실적으로 불 가능하고 일반 시민들에게 누구나 원한다면 쉽게 건강 관리 및 예방 차원의 자기 맞춤형 헬스케어서비스를 제 
공한다면 국민들의 건강 관리에 도움이 될 것이다.

우리나라는 초고속 인프라와 IT강국으로 스마트폰 가 입자수가 3년만에 3000만명을 넘어서고 있는데 이는 국 민 10 명중 6 명이 스마트폰을 사용하고 있음을 나타낸다. 스마트폰이 주도하는 스마트 혁명은 일상생활의 변화는 물론 IT산업과 경제 전반의 패러다임을 변화시키고 있다 [3]. 검색, 교통, 지도 등의 생활 밀착형 앱과 무선인터넷 의 이용으로 삶이 더 편리해졌다. 스마트폰은 일상생활, 일과 비즈니스, 소통 그리고 엔터테인먼트의 종합플랫폼 으로 진화하고 있다[1]. 개인의 건강관리를 위해서 이러 한 스마트기기들을 활용할 수 있다면 스마트폰으로 인한 역기능들을 순기능으로 전환 할 수 있을 것이다. 그러나 이러한 헬스케어 서비스와 관련해서 개인 정보보호가 시 급하며 특히 PHR(Personal Helath Record)는 개인의 사적 인 정보로써 보호되어야하며 헬스케어서비스 플랫폼에서 는 손쉽게 건강에 대한 정보를 제공하거나 제공받을 수 있지만 개인의 프라이버시 침해와 개인 정보보호가 우선 되어야하므로 사용자의 역할에 따른 접근제어를위해서 역할 기반 접근제어 모델을 적용하는 것이 필요하다.

\subsection{Role-Based Access Control Model}

$\mathrm{RBAC}$ 모델을 이용한 접근제어 기술은 정보보호의 기 본 분야중의 하나로 보안관련 시스템과 다양한 컴퓨팅 환경에서 적용되고 있는 기반기술이다. 특히 RBAC모델 은 역할(Role) 개념을 사용하여 엔터프라이즈급의 대형 시스템에서 사용자가 자신의 책임범위 안에서 허가된 자 원만을 접근 가능하도록 한다. 유비쿼터스 환경에서의 접 근제어, 애플리케이션 수준의 접근제어, 개인정보 프라이 버시 보호 등을 위해서는 $\mathrm{RBAC}$ 모델을 적용하는 것이 필수적이다.

$\mathrm{RBAC}$ 은 대단위 네트워크의 복잡성과 보안관리의 용 이성 비용감소 등에 큰 효과가 있어 다양한 환경에서 적 용되고 있다. 역할기반 접근제어는 조직의 구조와 연동하 여 직책 혹은 역할에 따라 보안 등급이 부여되고 사용자 는 특정 직책을 부여받으면 그에 대응하는 권한을 획득 한다. 따라서 직책 혹은 역할에 따른 권한이 조직의 보안 정책에 따라 결정되면 각 사용자는 역할만을 배정 받게 된다. 사용자가 역할을 부여받거나 역할들 간의 계층구조 등으로 발생되는 복잡성은 역할기반 접근제어모델에서 관리가 되므로 보안관리가 용이해진다. RBAC 모델은 사 용자가 조직의 정보자원을 임의로 접근할 수 없도록 하 는 것이다. 사용자는 역할을 부여받았을 때에만 그 역할 에 상응하는 권한을 가지게 된다. 즉 사용자는 역할의 수 행에 필요한 최소한의 자원에 대한 접근만이 허용된다. 기본 RBAC 모델의 구성 요소는 사용자(U:User)와 하나
혹은 그 이상의 객체에 대한 특정 접근 모드의 승인을 나 타내는 역할(R:Role), 사용자 배정(UA: User Assignment) 와 인가 권한(P:Permission), 세션(S:Session) 이다. Fig. 3 은 일반적인 역할 기반 접근제어 모델을 나타낸 것이다 $[10,11]$.

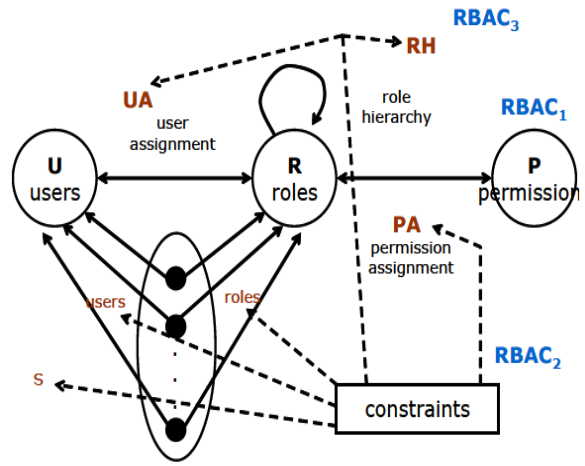

[Fig. 3] Role based access control model

[Table 1] The basic components of RBAC security model

U(User) : Set of Users

R(Role) : Set of Roles

$\mathrm{P}($ Permission) : Set of Permissions(read, write, execute, append, delete, update)

$\mathrm{S}$ (Session) : Set of Sessions

C(Constraints) : Set of Constraints

UA : User Assignment

PA : Permission Assignment

SA : Session Assignment

$\mathrm{RBAC}$ 보안모델의 구성요소는 Table 1 에 기술되어 있 다. 개인 맞춤형 헬스케어 서비스 플랫폼에 적용하기 위 해서는 일반적인 RBAC 의 구성요소들을 확장하거나 상 세정의하며 사용자나 역할에 따른 접근제어를 구현할 수 있도록 RBAC 보안 모델을 애플리케이션 도메인에서 적 용될 수 있게 상세 정의해야 한다.

다음 절에서는 $\mathrm{RBAC}$ 기반 개인 맞춤형 헬스케어 서 비스 플랫폼에 대하여 상세 기술한다.

\section{RBAC 에 기반한 개인 맞춤형 헬스케어 서비스 플랫폼 모델}

IT융합 기술의 발전으로 $\mathrm{u}$-헬스케어 서비스는 기존의 전염병 예방(헬스케어1.0)에서 ICT 기술을 통한 질병 치 
료 서비스로 기대수명 연장(헬스케어2.0) 으로 변모하였 다가 예방과 관리를 통한 건강 수명 연장을 추구하는 헬 스케어 3.0 으로 발전하고 있다. 헬스케어 3.0시대의 핵심 키워드는 일상관리화, 개인 맞춤화, 환자 중심화, 진단 치 료의 미세화 등이다[2]. 일상 관리화는 병원 치료 중심에 서 예방 건강관리 중심으로 발전하는 것을 의미하며 개 인 맞춤화는 치료방식이 개인특성을 고려하지 않는 표준 처방에서 유전적 소인과 체질을 고려하는 맞춤치료 방향 으로 발전하고 있음을 의미한다. 또한 진단 치료 미세화 는 진단치료의 정밀도가 향상되어 조기진단이 가능함을 나타내며 환자 중심화는 진단에서 사후 관리까지 전 과 정에서 환자의 편익과 효용이 극대화 되는 방향으로 발 전함을 의미한다.

이러한 헬스케어서비스의 진화에 초점을 맞추어 본 논 문에서는 환자 중심의 개인 맞춤형 헬스케어 서비스 플 랫폼에 개인정보보호와 프라이버시 침해 방지를 위한 역 할기반 접근제어모델을 적용한 보안 모델을 기반으로 개 인이 언제 어디서나 안심하고 건강관리를 할 수 있도록 개인 맞춤형 건강정보 관리 서비스 플랫폼을 설계한다.

\section{1 개인 맞춤형 헬스케어 서비스 플랫폼 워크플로우}

본 논문에서 제안하는 개인 맞춤형 헬스케어 서비스 플랫폼 모델에서 사용자는 일반인과 환자 그리고 전문의 료진이나 영양사, 헬스 트레이너 등 모든 사용자들이며 사용자들은 언제 어디서나 스마트 기기를 이용해서 건강 정보서비스나 건강관리를 수행할 수 있다. Fig. 4는 본 논 문에서 제안하는 맞춤형 건강정보 서비스에 대한 워크플 로우이다.

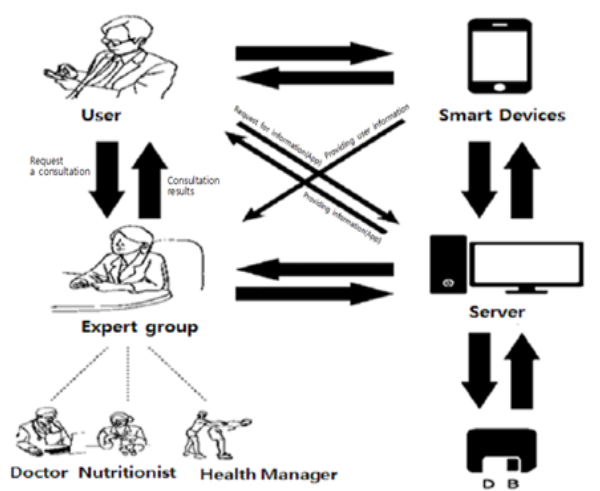

[Fig. 4] Workflow of personal healthcare service platform

개인 맞춤형 헬스케어 서비스 플랫폼을 통해서 사용자 들은 누구나 건강정보 제공자 혹은 구매자가 될 수 있고
개인적인 건강관리도 가능하다. 또한 의사나 간호사 영양 사 헬스매니저 등 전문가 그룹에 포함된 사용자들은 건 강정보 구매자가 원할 경우 다양한 정보를 제공하게 된 다. 전문가 그룹의 사용자들 역시 건강정보 구매자 혹은 제공자가 될 수 있다.

따라서 자신의 전문지식 혹은 치료방법 및 완치 결과 등 입으로만 전해지던 다양한 건강관련 정보들을 신뢰성 을 전체로 확보할 수 있으며 자신의 지식을 다른 사람에 게 판매할 수 있다. 또한 플랫폼내에는 건강정보 에이젼 트가 있어 다양한 건강정보들이 저장된 건강 정보 데이 터베이스에서 건강정보들을 분류하고 유용한 건강정보들 을 탐사하여 구매자에게제공하게 된다. 또한 스마트기기 를 통해서 언제 어디서나 신체데이터를 측정하고 섭취한 음식량 운동량등을 입력하여 개인별 건강관리를 체크할 수 있으며, 전문가 그룹에서 제공하는 진단지식 및 식단, 운동방법 및 종류 등도 개인 맞춤형으로 제공될 수 있으 므로 종합적인 개인 건강관리가 가능하다.

기존의 단순한 환자 정보를 저장하는 병원 데이터베이 스와 달리 일상생활의 생활 패턴인 수면, 식이, 운동, 감 정의 변화 등에 대한 정보를 추가적으로 수집되며, 유사 한 환자의 질환과의 연관성 등을 분석하기 위해 대용량 데이터 마이닝 분석 기술(패턴인식, 분류)을 활용하여 맞 춤형 건강관리 서비스가 가능하며, 스마트 기기를 이용하 여 자신의 건강상태에 대해 언제, 어디서나 모니터링 및 정보 제공이 가능한 최신의 기술을 적용하여 구축될 수 있다.

제안하는 서비스 플랫폼의 헬스케어 데이터를 이용한 생활패턴 서비스는 스마트 기기를 통해 수집되는 음식물, 수면, 운동량, 감정에 대한 정보와 질환의 관련성을 분석 하여 어떠한 음식이 신체에 변화를 주며, 음식물과 운동 량에 대한 정보를 통계 및 데이터 분석기법을 활용하여 식단에 대한 추천이나 운동에 대한 추천 서비스가 가능 하다.

\section{2 개인 맞춤형 헬스케어 서비스 플랫폼 상세기능}

Fig. 5는 환자 중심의 개인 맞춤형 헬스케어 서비스 플 랫폼의 상세 기능을 포함한 개념모델을 보여준다.

Fig. 5에서 알 수 있듯이 헬스케어 서비스 플랫폼은 4 개의 핵심적인 기능으로 나누어진다. 첫 번째 서비스는 스마트 기기를 이용한 헬스 데이터 자가 관리 서비스이 며 두 번째 서비스는 개인 건강정보(PHR) 관리 및 교환 서비스이고 세 번째 서비스는 의료정보 판매 서비스 그 리고 네 번째 약물정보 검색 서비스로 구성된다. 각각의 세부 기능에 대한 상세 설명은 다음과 같다. 


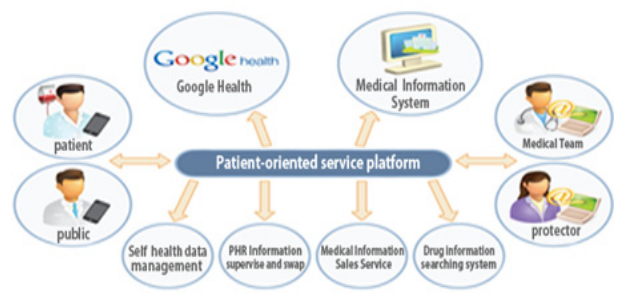

[Fig. 5] Conceptual diagram of patient oriented healthcare service platform

\section{(1) PHR 정보 관리 및 교환 서비스 기능}

현재 병원 정보시스템은 병원마다 데이터베이스 설계 및 진료기록에 대한 표준 포맷이 없어 환자에 대한 기본 정보를 포함하여 외부병원과 진료 정보를 교환하는데 있 어 문제점이 많이 나타나고 있다. 의료정보에 대한 표준 으로 HL7이 많이 사용되고 있지만, 미국 의료체계에 맞 추어져 방대하게 설계되어 있기 때문에 국내에 적용하는 데 많은 문제점이 있다. 현재 구글 헬스에서 사용하고 있 는 CCR 표준은 핵심적인 내용에 대해 정의하고 있어 개 인의 건강상태에 대한 정보와 진료 기록에 대한 정보를 표현하기에 매우 적합한 형태이다.

서울대병원, 아주대학교 병원, 가천길병원을 중심으로 $\mathrm{XML}$ 기반의 $\mathrm{CCR}$ 표준에 대한 연구와 개발이 진행되고 있으며, 본 논문에서 제안하는 개인 맞춤형 스마트 헬스 케어 서비스 플랫폼에서는 환자에 대한 기본적인 정보를 포함하여 진료정보 데이터에 대해 $\mathrm{CCR}$ 를 기반으로 데이 터를 저장하고 메시지 변환 및 송수신 방식을 채택하였다.

\section{(2) 스마트 기기를 이용한 헬스 데이터 자가관리 서비스 기능 (헬스로그)}

고혈압, 당뇨 등의 만성질환자와 비만인은 음식, 운동 량, 수면 등 일상생활에 대한 관리가 요구되며, 제안 기술 은 사용자가 일상생활에서 발생하는 행위 및 감정에 대 해 스마트 폰을 사용하여 실시간 기록하고 서버에 저장 하며, 서버에 저장된 일상생활 기록 및 통계정보는 전문 가 상담시 활용하거나 데이터분석 기법을 이용하여 유용 한 패턴에 대한 맞춤 서비스를 지원하게 된다.

본 논문에서 제안하는 스마트기기를 이용하는 헬스로 그 서비스는 일상생활 전반에서 발생하는 행위 사건들의 발생빈도, 연관관계, 순차 및 반복 관계 등에 대한 데이터 분석기술을 적용하여 사용자의 질환과 건강상태에 따른 맞춤 서비스 지원 등의 차별화된 서비스를 이른다.

예를 들자면 예1) 당뇨와 고혈압을 가진 태음인 체질 환자의 저녁 식단을 추천, 예2) 금일 섭취된 음식량과 운 동량을 고려한 칼로리 정보, 예3) 날씨와 감정변화 상태 이용한 우울증 개선 정보 제공 등의 서비스가 가능하다.
사용자 관점: 제안하는 “헬스로그" 어플 제품은 일반 인, 만성질환자, 비만인이 스마트 폰을 이용하여 언제 어 디서나 손쉽게 행위 및 감정상태 데이터를 서버에 전송 하여, 이력정보를 관리가능하고 각종 통계 및 패턴 정보 를 활용하여 자가 진단이 가능하다.

전문가 관점: 전문가(의사, 헬스매니저, 영양사 등)는 사용자의 모든 일상생활 데이터와 패턴 정보를 활용하여 질환을 예측하고 식습관을 개선하는 등의 전문적인 지식 을 제공하며, 정기적인 병원 내원시 환자의 질환과 생활 습관에 따른 맞춤형 건강관리 서비스가 가능해진다.

\section{(3) 개인 맞춤형 의료정보 구매 및 판매 서비스}

기존의 종이 차트로 관리되던 의무 기록 관리 방식에 IT 기술을 접목하여 병원에서 발생하는 모든 의료 정보 를 일체의 수정 없이 모두 전산화하는 방식을 전자 의무 기록(Electronic Medical Record) 방식이라 한다. 이러한 전자 의무 기록 방식은 환자를 진료하면서 발생하는 모 든 형태의 의료 정보, 예를 들어, 환자별 건강 상태, 환자 별 병력, 환자별 검사 결과, 환자별 처방 결과, 환자별 약 물 반응, 환자별 입원/퇴원 기록 등을 일정한 데이터베이 스에 기록하는 방식이다. 특별한 질병을 앓고 있는 환자 들은 자신과 유사한 상황에 있는 다른 환자들이 어떠한 치료를 받고 있는지, 또는 어떠한 방법으로 질병을 극복 하였는지 등에 관한 정보를 얻고 싶어 하는 경우가 많이 있지만 환자 자신이 과거 진료 기록 등 전산화된 데이터 에 접근할 수 없기 때문에 다른 환자에게 전문적인 정보 를 제공하거나 제공받을 수가 없고, 입소문으로만 정보가 전달되어 정보의 왜곡이 일어날 가능성이 크다. 환자 중 심의 개인 맞춤형 스마트 헬스케어 서비스 플랫폼에서는 이와 같은 문제점들을 해결하기 위해, 의료정보 데이터베 이스를 구성하고 구매자의 구매정보와 유사도가 높은 의 료정보를 검색하여 구매자에게 제공함으로써, 환자와 유 사한 상황의 다른 환자의 의료정보를 구매자가 구매할 수 있고 이를 참조하여 질병의 치료에 도움을 줄 수 있도 록 하고, 아직까지 활용도가 낮은 의료정보를 적극적으로 활용할 수 있는, 개인 맞춤형 의료정보 판매 서비스 제공 방법을 제공하게 된다.

또한 서비스 제공 서버가 온오프라인 네트워크를 통해 수집한 의료정보를 추가하여 더욱 풍부한 의료정보 데이 터베이스가 구축되어 진다. 또한 의료정보를 구매하고자 하는 구매자에게는 서비스 제공 서버가 의료정보 데이터 베이스에서 구매자로부터 입력받은 구매정보와 유사도가 높은 의료정보를 검색하여 제공한다. 즉, 의료정보를 구 매하고자 하는 구매자가 서비스 제공 서버에 접속하여 구매정보를 입력하면, 서비스 제공 서버는 구축된 의료정 
보 데이터베이스에서 구매정보에 맞는 의료정보를 검색 하여 제공하는 서비스를 수행한다.

개인 맞춤형 의료정보 판매 서비스 제공 방법에서는 판매자로부터 입력받은 의료정보를 기준으로 등록된 구 매정보를 검색할 수 있으며, 유사도는 구매정보와 의료정 보가 일치하는 수에 따라 결정하게 된다. 일치하는 수가 많을수록 유사도가 높은 것으로 판단하게 되고 구매정보 와 의료정보가 소정의 수 이상 일치하는 경우에 검색된 결과로 추출할 수 있게 된다.

\section{(4) 약물정보 검색 및 제공 서비스}

의약품 소비자인 일반인들은 각종 약물에 대한 지식이 부족하기 때문에, 의사나 약사가 처방해 준 약물의 종류 나 효능, 성분 등을 알지 못하고 약물을 복용하는 경우가 많다. 최근, 병의원에서는 가벼운 감기 증상에도 평균 5 알 정도의 약물을 처방하고 있어 약 과다 처방 및 과다 복용 문제가 대두되고 있고, 여기에는 소화제와 항생제 등 질병의 치료에 반드시 필요하지 않은 약물도 포함되 는 경우가 대부분이다. 환자가 처방 받은 약에 어떠한 효 능을 갖는 약물이 포함되는지 알고자 하더라도 일반적으 로 환자는 의약품에 대한 지식이 부족하기 때문에, 환자 가 약물의 형태만 보고 그 효능이나 성분을 짐작하는 것 은 불가능하다.

위와 같은 문제점들을 해결하기 위해 개인 맞춤형 스 마트 헬스케어 서비스 플랫폼에서는 약물 촬영 사진으로 부터 약물의 형태를 검출하고 검출된 약물의 형태를 약 물 데이터베이스와 비교하여 약물에 대한 정보를 추출하 여 제공함으로써, 사용자가 자신이 복용하는 약물에 대한 정보를 약물 촬영 사진을 이용하여 쉽게 얻을 수 있어 안 심하고 약물을 복용할 수 있도록 하고, 약물의 폐기에 따
른 낭비와 약물의 오남용을 방지할 수 있는, 스마트 기기 를 이용한 약물 정보 검색 및 제공 방법을 제공하는 것이 가능하다.

\section{4. 개인 맞춤형 스마트 헬스케어서비스 플랫폼 소프트웨어 아키텍처}

개인 맞춤형 스마트 헬스케어서비스 플랫폼의 상세 기 능 명세를 구현하기 위한 소프트웨어 아키텍처를 설계한 다. 일반 사용자는 스마트 기기를 통해서 정보를 입력하 거나 건강정보 관련 서비스를 제공 받을 수 있으며 전문 가와의 상담요청 서비스를 제공 받을 수 있다. 또한 의사, 영양사, 헬스매니저 등 다양한 분야의 건강 관련 전문가 들은 일반 사용자의 상담에 응하거나 다양한 건강, 운동, 음식 관련 정보들을 제공해 줄 수 있으며 특정 건강 경계 정보를 제공해 줄 수 있다. 스마트 기기를 통해서 일반사 용자와 전문가들은 헬스케어 컨택트 서비스로 상호 연결 된다. 또한 사용자들 중 자신의 경험으로 습득하게 된 다양한 건강정보를 판매하기를 원한다면 건강정보 판매 서비스에 등록을 하게 되고 구매서비스를 원하는 사용자 는 자신이 관심을 가지고 있는 건강 정보와 유사한 정보 를 검색하여 구매할 수 있게 된다.이와 같은 개인 맞춤형 헬스케어 통합서비스 플랫폼을 위한 소프트웨어 아키텍 처는 Fig. 6에 도식화되어 있다. 개인 맞춤형 헬스케어 통 합서비스 플랫폼의 소프트웨어 아키텍처는 통합 건강 정 보 데이터베이스를 중심으로 9 개의 컴포넌트로 구성된다.

개인 맞춤형 스마트 헬스케어 서비스 플랫폼은 의료정 보 서비스 플랫폼기술, 맞춤형 환자 데이터 분석 기술, 정 보교환 표준화 기술, PHR 정보 관리 및 교환 서비스 개

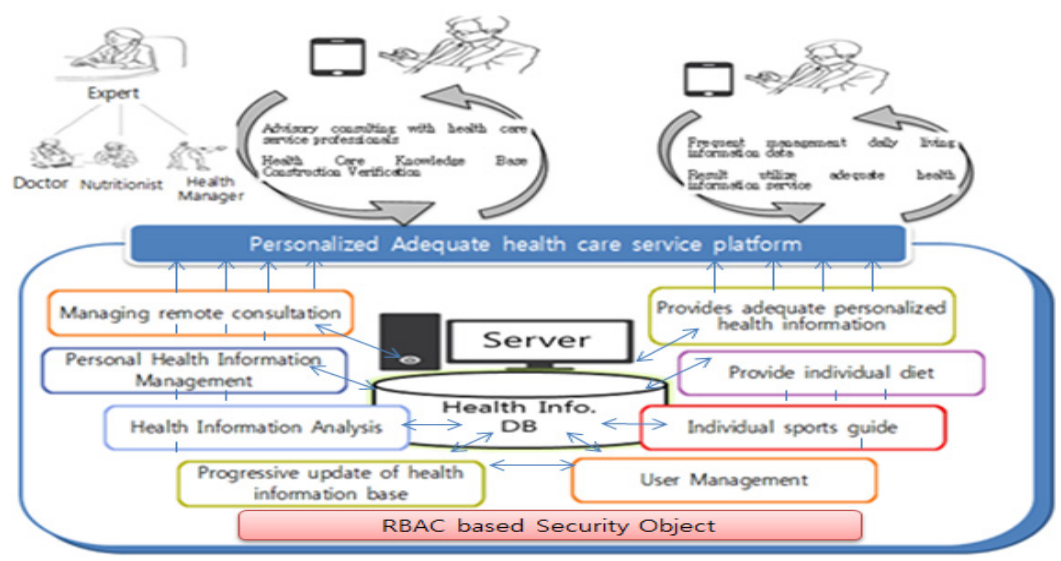

[Fig. 6] Software architecture of the proposed personal healthcare service platform with RBAC 
발, 스마트폰 기반의 개인 맞춤형 건강정보 관리를 위한 앱 개발로 구현 중이다.

원격상담관리는 전문가와 일반 사용자의 원격상담을 수행하는 모듈이며 맞춤 건강정보 제공서비스 모듈은 사 용자의 건강상태에 따라서 건강 유의사항 들을 제공하는 모듈이다.

개인 건강 정보 관리기는 개인의 모든 PHR을 저장하 고 검색하는 기능을 수행하고 개인별 식단 제공 서비스 는 만성질환자 혹은 일반인 들이 개인의 건강상태 및 체 격조건, 기호식품 등을 고려하여 전문가들이 맞춤형 식단 을 제공할 수 있도록 해주는 서비스 모듈이다. 개인별 맞 춤 운동 제공 서비스는 개인의 키, 몸무게, 나이 등을 고 려하여 적절한 운동량과 운동의 종류, 운동시간 등을 제 공해주게 된다.

건강정보 분석기는 구매자가 원하는 건강정보와 유사 한 정보들을 추출하여 제공하게 되며 사용자들이 많이 구매한 유용한 건강정보에 대한 추천/조회수를 기반으로 신뢰도를 표시하게 된다.

역할기반 보안 객체는 개인 맞춤형 헬스케어 서비스 플랫폼의 보안정책과 사용자에 따른 의료정보 접근제어 정책 및 권한에 대한 specification과 rule 들을 포함하고 있다.

사용자 관리 모듈은 사용자들을 구분하여 권한을 부여 하고 개인의 정보보호를 위한 역할 기반의 접근제어 모 델을 적용하여 개인의 프라이버시와 관련된 정보들이 보 호될 수 있도록 사용자 관리와 사용자 정보보호 기능을 수행하게 된다.

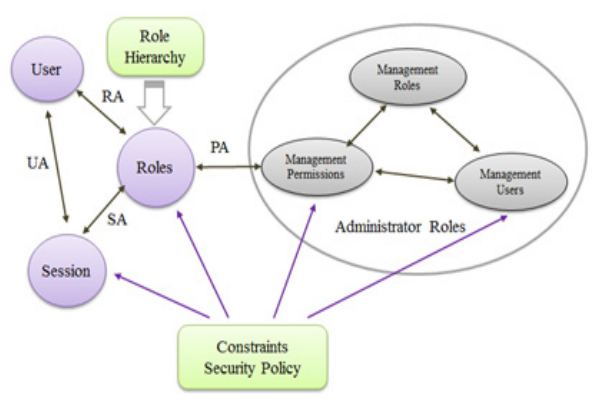

[Fig. 7] Extended RBAC security model

Fig. 7은 제안 시스템에 적용될 확장된 RBAC 보안모 델이다. 역할계층과 보안정책, 제약조건들의 명세를 기반 으로 관리자 역할을 강화하여 개인건강정보 서비스 플랫 폼에 적용한다. 이는 개인 정보보호와 프라이버시 침해를 최소화하기 위해 다양한 역할의 생성과 접근 권한을 부 여하기 위한 것이다.
Table 2는 개인 맞춤형 헬스케어 서비스 플랫폼에 적 용될 확장된 RBAC 모델의 구성요소들을 나타낸 것이다. 사용자에게 상황에 맞는 권한을 부여하기 위한 기본 단 위는 역할, 작업, 세션 등이다. 사용자의 역할에 따라 의 료정보 및 건강지식정보에 대한 접근 권한이 제한되며 수행하는 작업의 종류에 따라서도 적절한 접근 권한이 부여되며 해당 작업의 수행 세션동안에 접근권한 제한을 수행하게 되어 강제적인 접근제어가 수행될 수 있다.

[Table 2] The basic components of RBAC security model

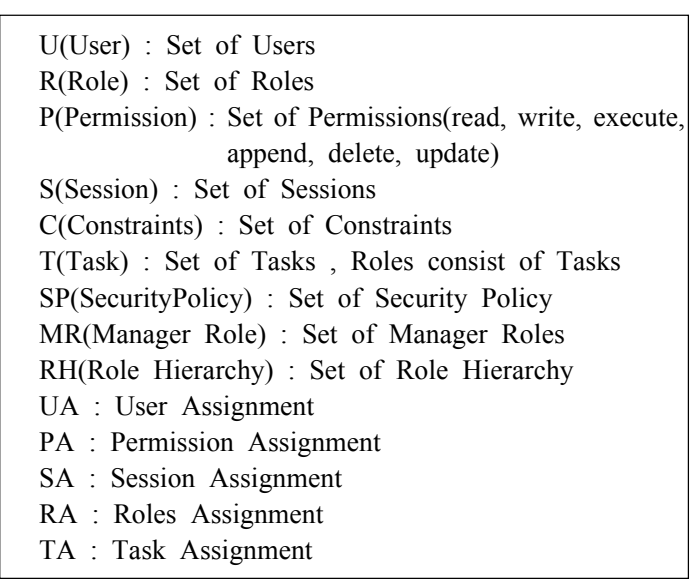

관리자가 다양한 역할이나 작업을 생성하여 이에 맞는 접근제어를 수행할 수 있게 되므로 유연한 정보보호 기 능이 제공되어 진다. RBAC에 기반한 개인 맞춤형 헬스 케어 서비스 플랫폼은 강제적 접근제와 임의적 접근제어 가 가능하여 가용성과 기밀성을 최대한 허용하는 보안객 체를 가지게 되어 신뢰성 있는 건강정보 통합 관리 서비 스를 수행할 수 있게 된다.

\section{6. 결론}

본 논문에서는 개인이 언제 어디서나 안심하고 건강관 리를 할 수 있도록 RBAC 기반의 개인 맞춤형 건강정보 관리 서비스 플랫폼을 설계하였다. 개인 맞춤형 헬스케어 서비스 플랫폼에 역할기반 접근제어 보안 모델을 적용하 여 개인정보보호와 프라이버시 침해 방지를 수행하여 안 전한 헬스케어 서비스를 제공할 수 있는 개인 맞춤형 헬 스케어서비스 플랫폼을 제안하였다. 제안된 개인 맞춤형 헬스케어 서비스 플랫폼을 통해 일상생활의 생활 패턴인 수면, 식이, 운동, 감정의 변화 등에 대한 정보를 추가적 으로 수집 저장이 가능하며, 유사한 환자의 질환과의 연 
관성 등을 분석하기 위해 대용량 데이터 마이닝 분석 기 술(패턴인식, 분류)을 활용하여 맞춤형 건강관리 서비스 가 가능하다.

\section{References}

[1] J.Y.Choi,, Y.S.Ko, S.CLee,, C.G.Kang, W.S.Choi,, "Healthcare 3.0 : A world of healthy life", CEO information Vol.831, Samsung Economic Research Institute, 2011,

[2] K.T.Oh, JE.Lee, "Smart Life revolutionary real and smartphone addiction", Internet and Information Security, Vol.3 No.4, 2012

[3] J.H.Park,,T.K.Hwangbo,"Healthcare IT Convergence Technology, Journal of Korea Information and Communications, Vol.28, No 5, 2011

[4] J.W.Song, S.H.Kim, M.E.Jung,"Protection of health information for u-healthcare service", Journal of Information Security, Vol.17, No 1, 2007

[5] S.H.Kim," "Health-IT convergence technology trends and forecasts (mainly U-health)", Journal of Electronics, Vol.37, No6, 2010

[6] HomMed Home Healthcare. www.hommed.com

[7] Philips Telehealth Solutions. www.healthcare.philips.com

[8] IBM m-Health Wireless Healthcare Solution. www-03.ibm.com/technology

[9] GE Healthcare. www.gehealthcare.com

[10] MobiHealth Project. www.mobihealth.com

[11] D.Ferraiolo, J.Barkely, and D. Kuhn, "A role based access control and reference implementation within a corporate intranet", ACM Transactions on Information and System Security, 1999.

[12] T.Rindfleeish, Privacy, information technology and health care, Communications of ACM,1997.

\section{송 제 민(Je-Min Song)}

[정회원]

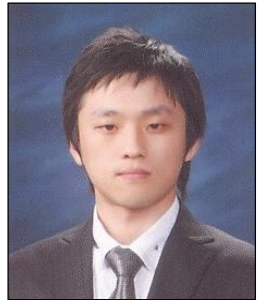

2011년 8월: 충북대학교 바이오 인포매틱스(공학석사)

- 2011년 8월 현재 : (주)터보소 프트 개발 팀장

- 2013년 3월 현재 : 충북대학교 정보산업협동과정 박사 재학

\section{김 명 식(Myung-Sic Kim)}

[정회원]

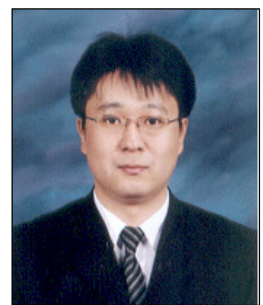

- 2013년 2월: 충북대학교대학원 정보산업공학협동과정 박사 수료

- 2010년 10월 현재 : 네오포스 (주) 책임연구원

<관심분야>

로봇제어, 상황인지, 프레임워크, $\mathrm{PMO}$

정 경 자(Kyeong-Ja Jeong)

[정회원]

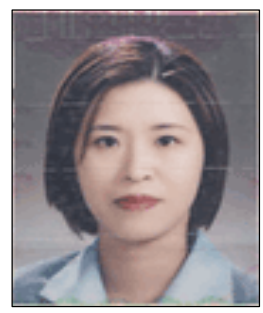

- 1998년 2월: 충북대학교대학원 전자계산학과(이학박사)

- 1995년 3월 현재 : 충청대학교 국방정보통신과 교수

<관심분야>

데이터베이스, 정보보안, 클라우드컴퓨팅

신 문 선(Moon-Sun Shin)

[정회원]

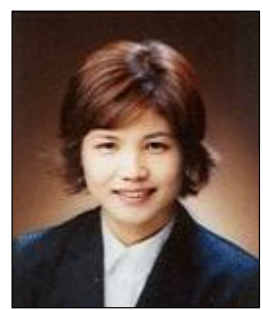

- 2004년 8월: 충북대학교대학원 전자계산학과(이학박사)

- 2005년 8월 현재 : 건국대학교 컴퓨터공학과 교수

<관심분야>

데이터베이스, 정보보안, 헬스케어시스템, 상황인지, RFID 보안

<관심분야>

의료정보, 바이오인포매틱스, 영상처리 